\title{
A SIMULATION STUDY OF QUALITY INDEX IN MACHINE-COMPONENT GROUPING
}

\author{
By \\ Hamid Seifoddini \\ Associate Professor \\ Industrial and Manufacturing Engineering Department \\ University of Wisconsin-Milwaukee \\ Manocher Djassemi \\ Assistant Professor \\ Department of Industrial Studies \\ University of Wisconsin-Plattville
}

\begin{abstract}
Simulation modeling is employed to determine the effectiveness of quality index in screening machine-part matrices for the development of cellular manufacturing systems.
\end{abstract}

\section{INTRODUCTION}

Cellular manufacturing is the organization of production into independent manufacturing units called "machine cells." A machine cell has the capability of processing a range of parts (part-family) with similar manufacturing requirements. This reduces the need for formation of lots of large sizes for achieving the economy of scale. Consequently, cellular manufacturing systems are more efficient and provide more flexibility in responding to consumers demand $[2,6,7,9]$.

The main data for machine cell formation is organized in a machine-part matrix with one/zero entries representing presence/absence of operations on machines. A machine-part matrix is converted into a block diagonal form before it is used for the development of a cellular manufacturing system. In the block diagonal form, one entries are concentrated into blocks along the diagonal of matrix representing the machine-component groups. The structure of a machine-part matrix has a great impact on the performance of the corresponding cellular manufacturing system [3].

To evaluate the block diagonal machine-part matrix for the development of cellular manufacturing systems, a number of grouping measures have been developed $[3,8]$. Among these measures, quality index (QI) is more effective in evaluating the performance of a cellular manufacturing system based on its machine-part matrix [8]. QI is based on the data in the machine part matrix, the production volume of parts in the product mix, and the processing times of manufacturing operations. 


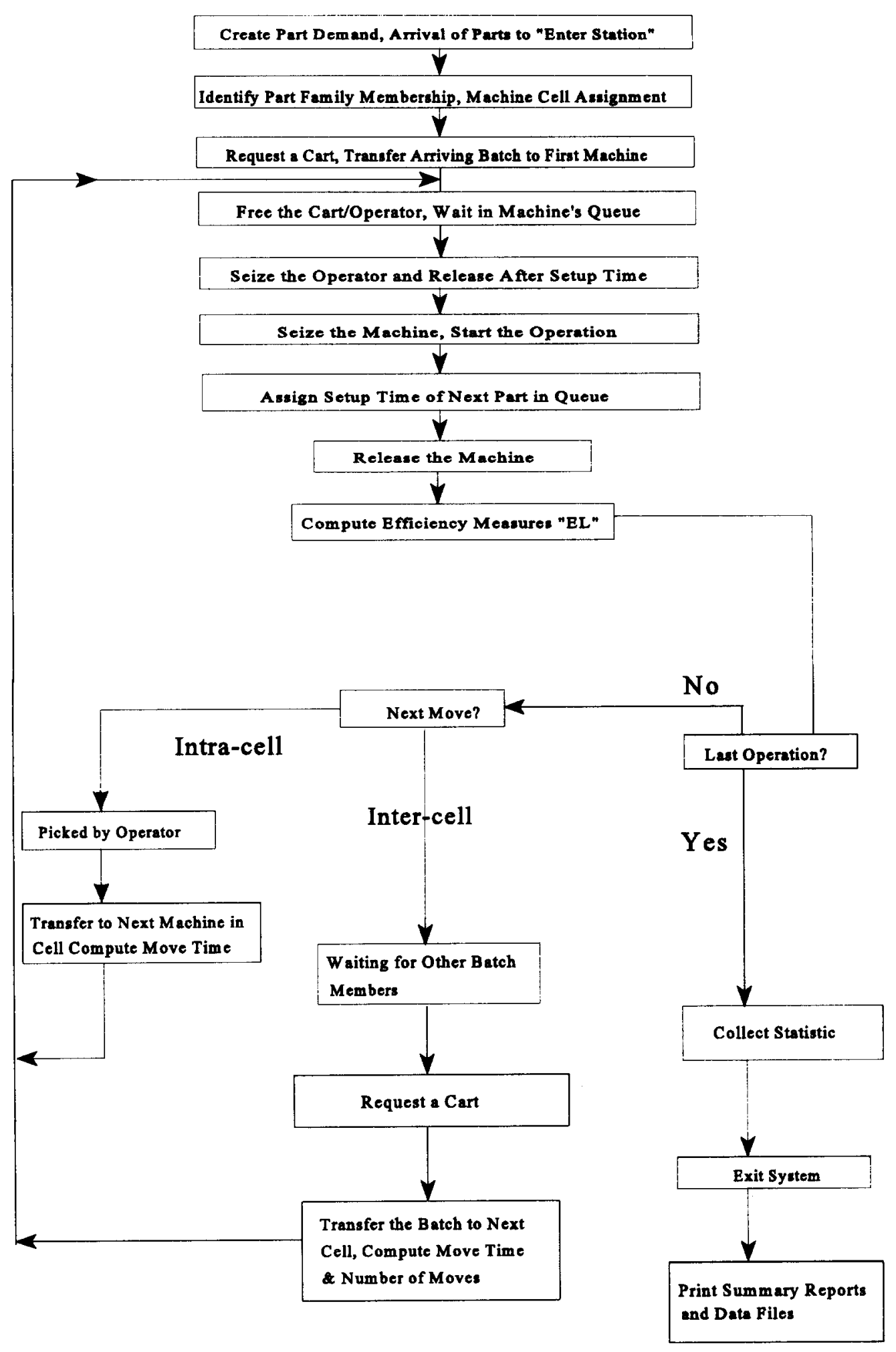

Figure 1. Flow Chart of the Procedure for Performance Evaluation 
In this paper, simulation modeling will be used to determine the effectiveness of QI in screening the machine-part matrices for the development of cellular manufacturing systems.

\section{DEFINITION OF THE PROBLEM}

Though cases of successful implementation of cellular manufacturing systems are numerous, the conversion from job shop to cellular manufacturing may not always result in higher productivity. Some studies show that the conversion from job shop to cellular manufacturing leads to longer waiting lines, higher-in-process inventories, and lower machine utilization [1,5]. Therefore, prior to the development of a cellular manufacturing system, it is necessary to evaluate the manufacturing system for determining its suitability for cellular manufacturing.

QI has been specifically developed to evaluate manufacturing systems based on their block diagonal machine-part matrices. A simulation study by authors show that QI is the most consistent grouping measure in predicting the performance of a cellular manufacturing system based on the structures of its block diagonal machine-part matrix. Therefore, this measure can be used to quantify the characteristics of a machine-part matrix.

Since QI is only a measure of the quality of the machine-part matrix, it is necessary to evaluate the performance of the cellular manufacturing system before and after conversion to cellular manufacturing to determine its effectiveness.

\section{SOLUTION METHODOLOGY}

The flow chart of the procedure for the comparison of job shop and cellular manufacturing systems based on QI and simulation modeling is presented in Figure 1. The detailed description of the model, its input, and its output is given in reference [4]. The procedure includes three important functions as listed below.

1. Formation of machine-component groups

2. Calculation of QI for machine-part matrices

3. Performance evaluation of manufacturing systems under job shop and cellular manufacturing.

The machine-part matrix and other detailed data on manufacturing systems used in this study are given in reference [4]. The simulation results for two extreme values of QI, 0.68 and 1.0 are given in Tables 1 and 2.

Table 2. Simulation Results for $\mathrm{QI}=.68$

\begin{tabular}{||c|c|c|c|c||}
\hline $\begin{array}{c}\text { Type of } \\
\text { Manufacturing } \\
\text { Systems }\end{array}$ & $\begin{array}{c}\text { Mean Flow } \\
\text { Time } \\
\text { (hours) }\end{array}$ & $\begin{array}{c}\text { Mean WIP } \\
\text { (parts) }\end{array}$ & $\begin{array}{c}\text { Mean } \\
\text { Setup } \\
\text { Time \% }\end{array}$ & $\begin{array}{c}\text { Mean } \\
\text { Operator } \\
\text { Productivity } \\
\text { Parts/Shift }\end{array}$ \\
\hline Job Shop & 128 & 3.02 & 19.9 & 3.17 \\
\hline $\begin{array}{c}\text { Cellular } \\
\text { Manufacturing }\end{array}$ & 154 & 4.71 & 5.4 & 3.40 \\
\hline
\end{tabular}


Table 3. Simulation Results for $Q I=1.00$

\begin{tabular}{|c|c|c|c|c||}
\hline $\begin{array}{c}\text { Type of } \\
\text { Manufacturing } \\
\text { System }\end{array}$ & $\begin{array}{c}\text { Mean Flow } \\
\text { Time } \\
\text { (hours) }\end{array}$ & $\begin{array}{c}\text { Mean WIP } \\
\text { (parts) }\end{array}$ & $\begin{array}{c}\text { Mean } \\
\text { Setup } \\
\text { Times \% }\end{array}$ & $\begin{array}{c}\text { Mean } \\
\text { Operator } \\
\text { Productivity } \\
\text { Parts/Shift }\end{array}$ \\
\hline Job Shop & 82 & 2.96 & 18.8 & 3.48 \\
\hline $\begin{array}{c}\text { Cellular } \\
\text { Manufacturing }\end{array}$ & 66.3 & 2.13 & 3.9 & 3.94 \\
\hline
\end{tabular}

As can be seen, an increase in the value of QI leads to substantial improvement in the performance measures for the cellular manufacturing system.

\section{CONCLUSION}

The evaluation of block diagonal matrices provides useful information on the suitability of a manufacturing system for conversion to cellular manufacturing. QI is an effective grouping measure for the evaluation of machine-part matrices. Simulation modeling serves as an effective tool for performance evaluation in the development of cellular manufacturing systems.

\section{REFERENCES}

[1] Ang, C. P., Willey, P. C., "A Comparative Study of the Performance of Pure and Hybrid Group Technology Manufacturing Systems Using Computer Simulation Techniques," Int. J. Prod. Res., Vol. 22, No. 2, pp. 193-233, 1984.

[2] Burbidge, J., "Change to Group Technology: Process Organization is Obsolete, "Int. J. Prod. Res., Vol. 30, No. 5, pp. 1209-1220, May 1992.

[3] Chandrasekharan, M. P. and Rajagopalan, R., "Groupability: An Analysis of the Properties of Binary Data Matrices for Group Technology, " Int. J. Prod. Res., Vol. 27, No. 6, pp. 1035-1052, 1989.

[4] Djassemi, M., "The Use of Machine-Grouping Efficiency in Comparison of Job Shop and Cellular Manufacturing Systems: A Simulation Study," Unpublished Ph.D. Dissertation, 1994, Department of Industrial and Manufacturing Engineering, University of Wisconsin-Milwaukee.

[5] Flynn, B. B. and Jacobs, F. R., "A Simulation Comparison Group Technology with Traditional Job Shop Manufacturing," International Journal of Production Research, 1986, Vol. 24, No. 5 pp. 1171-1192.

[6] Hyer, N. L., "The Potential of Group Technology for U. S. Manufacturing," $J$. of Operation Management, Vol. 4, No. 3, pp. 183-201, 1984.

[7] Hyer, N. L., Wemmerlov, "Group Technology and Productivity," Harvard Business Review, July/August 1984. 
[8] Seifoddini, H. and Djassemi, M., "Analysis of Efficiency Measures for Block Diagonal Machine-Component Charts," 16th International Conference on Computers and Industrial Engineering, Ashikaga, Japan, 1994.

[9] Wemmerlov, U. and Hyder, L., "Cellular Manufacturing in the U. S. Industry: A Survey of Users," Int. J. Prod. Res., Vol. 21, No. 9, pp. 1511-1530, 1989. 